\title{
Research on the Financial Support of Rural Banks in Jilin to the Development of County Economy
}

\author{
Hongwei Cui \\ School of Finance, Jilin Business and Technology College, Changchun, Jilin Province, China \\ 172740537@qq.com
}

\author{
Keywords: Rural banks; County economy; Financial support
}

\begin{abstract}
This is the actual need to adapt to the rural bank and county economy in Jilin province have entered a new stage of development, put forward the development strategy research of the cooperative rural banks and county economy in Jilin Province, not only systematically summary existing results of relevant research and can promote it. In this paper, the empirical analysis and normative analysis, qualitative analysis and quantitative analysis are used to study the relationship between rural banks and economic development in Jilin province. This paper is divided into three parts, starting from the analysis of the current situation of the development of rural banks in Jilin Province, sort out the main measures of rural banks in Jilin province to support the development of county economy, analysis of existing in the service of county economic development problems of the rural banks, finally put forward countermeasures. Through the research on issues related to the thesis draws a conclusion that the rural banks in Jilin province has a certain positive role in promoting the development of county economy, but there still exist some shortcomings, need to constantly improve the support effect in order to achieve better.
\end{abstract}

\section{Introduction}

In recent years, the problem of "agriculture, countryside and farmers" has been paid more and more attention. As one of the important means to promote the development of county economy, the importance of rural finance is becoming more and more important. Jilin Province as one of the first pilot the establishment of village banks, to promote the formation of new rural financial system in rural areas, support the construction of new socialist countryside, promote the harmonious development of economic and social progress and the county, has a very important significance. Most of the counties and cities in China have developed the rural banks, and as an important part of the rural financial system, which has gradually become the main force to support the county's economic development, and promote the development of county economy. However, the current situation, the development of rural banks in Jilin is still in its infancy, rural financial reform has not yet fully achieved the desired objectives and results. Therefore, how to promote the coordinated development of rural finance and county economy, how to support the county economic growth through the development of rural banks, has become the focus of the theoretical and practical research. [1]

\section{Development Status of Rural Banks in Jilin}

From 2007 the first rural bank began, as of March 2016, the opening of the rural banks in Jilin province increased to 52, as shown in Table 1, and another 3 are under construction: Tiexi silver village bank in Siping, Silver village bank in Tumen, Silver Village bank in Dehui.

Table 1 Number of opening of the rural banks in Jilin province

\begin{tabular}{|l|l|l|l|l|l|l|l|l|l|}
\hline region & $\begin{array}{l}\text { Changchu } \\
\mathrm{n}\end{array}$ & $\begin{array}{l}\text { Jili } \\
\mathrm{n}\end{array}$ & $\begin{array}{l}\text { Yanbia } \\
\mathrm{n}\end{array}$ & $\begin{array}{l}\text { Tonghu } \\
\mathrm{a}\end{array}$ & $\begin{array}{l}\text { Baichen } \\
\mathrm{g}\end{array}$ & $\begin{array}{l}\text { Songyua } \\
\mathrm{n}\end{array}$ & $\begin{array}{l}\text { Sipin } \\
\mathrm{g}\end{array}$ & $\begin{array}{l}\text { Liaoyua } \\
\mathrm{n}\end{array}$ & $\begin{array}{l}\text { Baisha } \\
\mathrm{n}\end{array}$ \\
\hline number & 13 & 8 & 6 & 5 & 5 & 5 & 4 & 3 & 3 \\
\hline
\end{tabular}


According to statistics, Jilin province rural bank employees a total of 1729 people, the village bank business loans totaled 15 billion 260 million yuan, an increase of 2 billion 560 million yuan over the beginning of 2014, an increase of 850 million yuan over the same period in 2013, compared with the growth rate of $62.5 \%$ compared with the beginning, the business deposits of 24 billion 10 million yuan, an increase of 3 billion 820 million yuan over the beginning of 2014, an increase of 170 million yuan more than in 2013 at the same time, compared with the growth rate of 49\% compared with the beginning. Jilin Province Rural Bank area distribution, Changchun area 13, Jilin 8, Yanbian 6, Tonghua, Baicheng and Songyuan area 5, Siping area 4, Liaoyuan and Baishan area each 3, as shown in Fig. 1, the Changchun area, Jilin area and Songyuan Area Rural Bank branch network distribution more. But the vast majority of rural banks in some urban and rural areas, and even more business outlets directly in the city. [2]

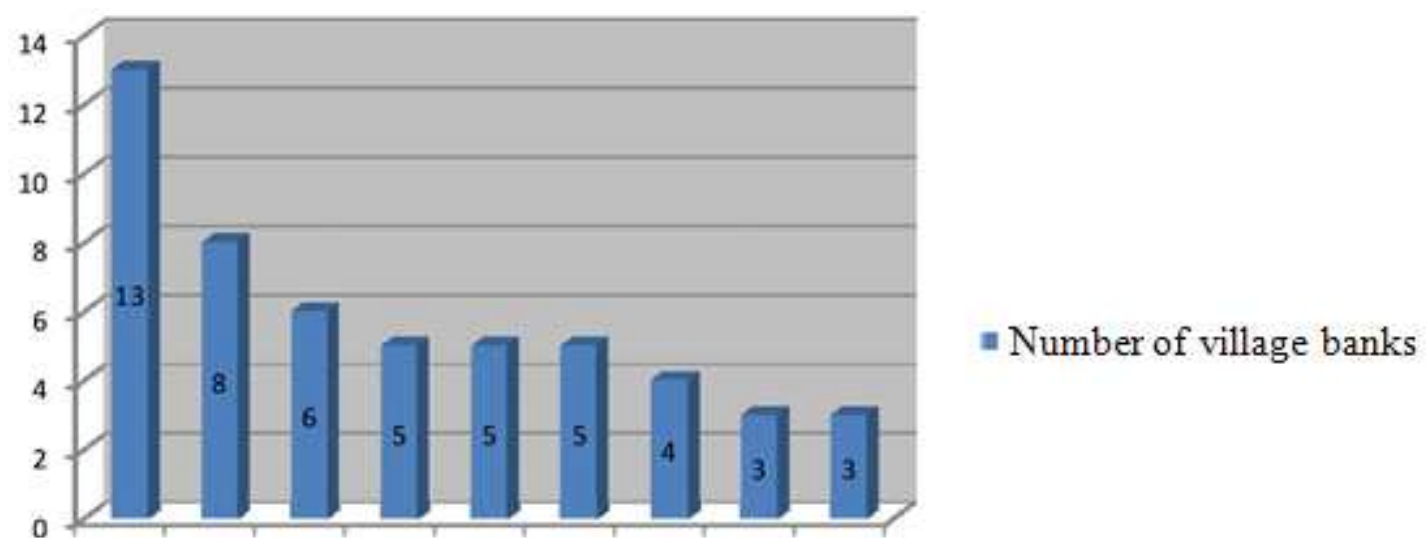

Figure 1. Regional distribution of rural banks in Jilin

\section{The Main Measures to Support the County Economy Development in Jilin}

Rural banks in Jilin support the county's economic development is mainly reflected in the following aspects: the gradual expansion of the business structure, innovative credit products, the advantages of the loan review process is obvious. Specific measures: Songyuan Ningjiang Huimin village banks carefully screening marketing plan and target customers, and according to the difference of enterprise financing needs, design personalized credit products, to achieve the service more professional, more comprehensive products, improve the success rate of sales. At present, Songyuan Ningjiang Huimin village banks have developed rice processing enterprise customers, "small oil" oil supporting enterprise customers, corporate clients, large shopping malls, customers of different industries such as building materials business park focus on target customer lists, reserve a large number of customer resources. Two is the implementation of business marketing, processing. In the shops mortgage, "Huinong treasure" and "young entrepreneurs" loan marketing process, complete the survey and investigation work, initially formed a "intensive" work pattern. Three is the implementation of embedded risk management, improve business efficiency. The formation of a unified business standards and risk control awareness, improve business efficiency. Four it is reasonable to determine the loan period, flexible repayment methods, Small and micro businesses loans. [3]

Da'an Huimin village banks to simplify loan procedures under the premise of risk control, put forward the "qualified customers, deposit loans as convenient as the" service concept, and establish with the report with the trial system, reasonably determine the running time. It is understood that in 2015 the bank through cooperation with Guarantee Corporation within 3 days of the Yongchang City, a large warehouse for the launch of credit funds of $\$ 5$ million to help companies acquire corn. The bank has also established a small and micro enterprise loans to the green channel, one by one by the exclusive customer service manager, and open procedures and time limits. At the same time, 
the bank also in-depth business, advanced services, active service to customer manager to go to the village to ensure that every village, every community has a person responsible for providing various financial services. In addition, the bank also took the initiative to publicity, to provide extended services for customers and other aspects of the family. It is understood that this year, the bank accumulated farmers, rural areas, agriculture loans 303 million 830 thousand yuan, of which planting \$75 million 600 thousand, aquaculture industry, 93 million 550 thousand yuan, the acquisition of food industry, \$102 million 100 thousand, small and micro enterprises $\$ 32$ million 580 thousand.[4]

Since 2012, 3 rural banks in Siping City Defeng village bank as the representative of the local rural cooperatives were combined with capital, innovative ways of rural financial services, through the "Rural Bank + cooperatives + farmers", develop the rural banks' capital strength strengths and mutual funds master farmers information advantage, "combination" out of a new way of rural financial service of the real farmers, effectively break the village bank villages and households difficult problem, but also provides reference for city finance into the rural financial market. [5]To explore the rural market, the rock Rong Feng Village Banks developed mainly in the "company + farmers", "small farmers loan", "civil service guarantee for farmers", "agricultural mortgage", "party business loan" and "women's re employment loan mainly agricultural loans. [6]

\section{Problems Existing in the Development of County Economy Supported by Village Banks}

Rural Banks to Implement the Service Policy is Difficult. First, the village banks show a large support small phenomenon. Because of its special background and conditions, the village bank determines its location of serving the county economy. Meanwhile, as a commercial bank, the nature of profit is also inherent. In the survey, we found that the various preferential policies and support policies for rural banks are very limited

The development of agriculture, rural areas and farmers can not be effectively unified. Under the background of the development of county economy, the resources of large enterprises are limited, and the risk of small and medium-sized enterprises is large. At present, the rural banks, small, decentralized business principles are difficult to implement, the specific performance of the loan amount is high, the loan to invest too much concentration. Two is a small rural banks supporting small and difficult to control the risk of conflict. Rural banks should not only carry out commercial operation, but also to carry out agricultural related policies related to small branch. But in the current economic environment of county agriculture, support small business credit risk is higher, rural banks how to ensure their own profit and development, but also can effectively carry out the relevant policies of business operation has become the support of local economic development problems.

The Source of Funds Restricts the Sustainable Development of Rural Banks. Opening time is short, customer resources are limited, which is the reality of the current rural banks. The lack of trust in the county people, coupled with its popularity is not high, the development of the credit business, payment and settlement services and other financial services are lagging behind, businesses and people do not fund the basic deposit in rural banks. Therefore, the village bank Xichu limited ability to absorb all kinds of deposits is very difficult, which restricts the development of rural banks. At the end of 12 2014, the balance of savings deposits of rural banks in Shuozhou was $\$ 690$ million, accounting for only about $6.5 \%$ of the county's savings deposits. [7]

The Lag of Network Equipment Hinders the Development of Rural Banking. The people's Bank of China stipulates that, in order to effectively improve the operational level of the village and town banks, the village banks that have the conditions may join the RMB bank settlement account management system and the network check Citizenship Information system. To achieve these conditions, we need to constantly improve the network equipment research and development, increase network technology support. Most of the rural banks have just started, there are difficulties in funding, for a large number of people to invest in the cost of their own development caused a serious burden. Therefore, the development of rural banks to better, network problems are: the means of payment problems, the current village banks also failed to achieve a comprehensive 
network and computerization, no online payment system, a lot of business can not be carried out properly; network credibility problems, rural banks can not realize informatization, cannot through the network authentication, leading enterprises and individuals in check, not certified bank information in a timely manner, resulting in the entire organization work efficiency is low, but also increased the amount of tasks; existing problems of anti-money laundering, rural bank scale, capital limited processing capacity, and cooperation and contact the outside world is relatively small, for the disposal of the funds is not enough one of the important issues in a timely manner, but also its development faces. These are due to the lack of network access to the Internet, the modern information system, leading to financial management ability defects, low management level of the account. These questions are addressed.[8]

\section{Countermeasures of Rural Banks Supporting County Economic Development in Jilin}

Increase Policy Support to Promote the Development of Rural Banks. In order to better serve the "farmers, rural areas, agriculture", and in the service of "farmers, rural areas, agriculture" process to achieve their own development and growth, the relevant departments should give the necessary policy support for rural banks. One is in the start-up phase of the rural bank business tax relief and income tax, to support its development; two is to accelerate the establishment of agricultural policy insurance institutions, to provide effective protection to the rural bank security funds; the three is to establish the necessary risk compensation mechanism, incentive mechanism establishment of village banks to serve the "farmers, rural areas, agriculture" and support the construction of new countryside. [9]

Establish Market Positioning Mechanism and Standardize Service Direction. First, the regulatory authorities to establish a sound market positioning mechanism. Through the improvement of evaluation system of agriculture support small town bank service quality, the "farmers, rural areas, agriculture" and the support of small and micro enterprises to invest and loans accounted for the specified location, the village bank grasp service county economy, in accordance with the direction of agriculture support small services, promote the "farmers, rural areas, agriculture" and the sustainable development of the balance between business relations, based on the reality of the development of the county the economy, increase efforts to support small agriculture. Secondly, to explore new business models, in terms of loan approval, process operation, interest rate mechanism and other aspects of innovation, for the region to meet the conditions of enterprises and farmers to provide a variety of convenient financial services. Third, the Bank launched the existing mature financial products, financial tools, technology and service mode, improve the core competitiveness in the county area of rural banks, and promote the important role of the financial business in the rapid development of county economy.

Efforts to Expand Funding Sources to Strengthen the Development of Rural Banks. Increase policy support efforts to promote the development of rural banks and rural banks in order to better serve the "farmers, rural areas, agriculture", and realize their own development in the process of serving the "farmers, rural areas, agriculture issues", the relevant departments should be given the necessary support policy of rural banks. One is in the start-up phase of the rural bank business tax relief and income tax, to support its development; two is to accelerate the establishment of agricultural policy insurance institutions, to provide effective protection to the rural bank security funds; the three is to establish the necessary risk compensation mechanism, incentive mechanism establishment of village banks to serve the "farmers, rural areas, agriculture" and support the construction of new countryside the. In addition to the state should support rural bank credit, efforts to reduce rural bank operating costs, reduce the risk of loss of policy support, rural banks should do the following work: one is to use a variety of media and the public platform to promote the establishment of the purpose and meaning of the rural bank, the village town bank to carry out related business, to guide the public to fully understand and positive recognition of village banks; two is the establishment of rural bank branches, expand the service radius; farmers, rural areas, agriculture banks each worker should reach deep "three agriculture", timely understanding of farmers, enterprise production and management situation, guide them to deposit idle funds to rural 
banks; four is to accelerate the infrastructure construction of rural banks, to attract customers to join us with modern means and quality service.[10]

Strengthening the Construction of Network Equipment to Improve the Efficiency of Financial Service. First, multi-channel financial service model innovation, expand the village bank service. General behavior of rural banks rely on, explore the establishment of self-help service stations, community service outlets and financial services and other characteristics of mobile station service channels in rural areas, effectively solve the disadvantages of rural bank outlets caused by insufficient, the maximum ability to provide high-quality, safe and convenient for customers of financial services in rural areas. The two is to strengthen the cooperation between the village banks and the banks or the banks to make up for the disadvantages of the rural banks due to the backward network technology to improve the level of financial services in rural banks. The three is to push for the core business system and other infrastructure construction, actively cooperate with the payment and settlement department, strengthen the rural bank network channel construction, improve the level of operation management system, improve rural bank financial services electronic level, as soon as possible and to have joined the payment system, credit management system and anti-money laundering monitoring system, as soon as possible enjoy the convenience of the service access network advanced system.

\section{Acknowledgements}

The Education Department of Jilin Province Project "Research on the Financial Support of Rural Banks in Jilin to the Development of County Economy" (JJKH20170199SK)

\section{References}

[1] Zhao Xue jing. The Research on Development of rural Banks in Jilin Province. Dissertation Submitted For the Master of Degree.2016.

[2] Luo Juncheng. A study on sustainable development in jilin peovince rural bank. Dissertation Submitted For the Master of Degree.2016.

[3] Hu Guoyou. Research on the innovation of financial products and services to support the development of small and micro enterprises. Journal of Jilin Financial Research.(2013) No. 2.

[4] Wang Tianwu. Da an Huimin village banking services countryside, agriculture and farmers. Rural financial times /2015/12/7 / 013 .

[5] Li Zhonghua. The path choice of village and town bank。Journal of Jilin Financial Research. (2014) No. 7.

[6] Qiao yonghai.Zu longbin. Research on the development of " Countryside, agriculture and farmers issues" supported by village banks. Journal of Jilin Financial Research. (2011) No. 6.

[7] Liang Jifeng. Investigation and Reflection on the status quo of rural banks supporting County Economic Development. Economist magazine. (2015) No. 7.

[8] Ren Hanjun. Research on the synergy between rural banks and county economic development 。 Journal of rural economics and technology.(2016).No7.

[9] Cheng Haihong. Reflections on the development of county economy supported by village banks. Western financial Journal, (2013) No. 6.

[10] He Fei. Sustainable development path of rural banks. China Finance magazine,(2015).No4 